\title{
Principle-Based Governance: Influence Outcomes through Values and Beliefs
}

\author{
Dr. Russell A. Horswill \\ Certified School Business Official \\ 3354 Coniston Crescent \\ Cumberland, British Columbia, V0R 1S0, Canada \\ Tel: 1-250-336-8883 E-mail: Russell.Horswill@gmail.com
}

Received: May 06, 2013 Accepted: May 27, 2013 DOI: 10.5296/jpag.v3i2.3653

\begin{abstract}
This article examines how public and not-for-profit governance boards can influence outcomes by asserting their values and beliefs on all levels of an organization. The purpose of this article is to present and apply a governance model call Principle-based Governance developed for public and not-for-profit organizations to a theoretical model calling for the creation of a hybrid/vector model of governance. The governance model presented focuses on providing assurance to constituents, fostering an organization that maintains sustainable balance, and engaged constituents in shared governance processes. Through the articulation of board governance (direct control), guiding the system (shared influence) and administrative empowerment (delegated authority) functions, the governance model provides clear demarcation between the role of the CEO and the board. It draws upon published research pertaining to effective governance and applied experience in implementing aspects of the Principle-Based Governance Model (Assurance). The article concludes that the governance model does address fully the primary intent of the hybrid/vector governance model.
\end{abstract}

Keywords: Public Governance, Not-for-Profit, Principle-Based, Assurance, Shared Governance, Sustainable Balance, Values and Beliefs 


\section{Introduction}

Public and Not-for-Profit (P-NFP) governance is under enormous pressure to transform from simple representative bodies that maintain fiduciary controls, to governance boards that provide assurance to constituents that their unique needs will be met now, and in the future (Carr, 2010). Accountable is no longer sufficient. Effective P-NFP boards seek to assure constituents that they can trust the organization to provide responsive services tailored to their specific needs. Through the application of The Public Assurance Paradigm indicators, P-NFP boards can answer: What results do we wish to assure are achieved? What results do we wish to assure are avoided? Improving organizational effectiveness and efficiency at the governance level will require systematic alignment with the external environment (Bradshaw, 2009).

P-NFP boards need to work to restore public trust, to demonstrate that they are stewards of the system and that stewardship is about meeting the ever-changing needs of their constituents. The general problem under study is that P-NFP boards are struggling as they attempt to transform themselves into effective governance bodies that will meet the needs of constituents. The specific problem is the void in access to, and application of, a governance model that will assist P-NFP boards achieve exceptional outcomes demanded by constituents. The purpose of this article is to present and apply a governance model call Principle-based Governance developed for public and not-for-profit organizations to a theoretical model calling for the creation of a hybrid/vector model of governance.

\section{Theoretical Framework}

Bradshaw, Hayday, and Armstrong (2007) posited that no single governance model correlates with effective board governance. The complex and dynamic relationships between board members, staff, and constituents suggests that the normative literature on organizational governance does not fully consider the ebb and flow adequately. Dynamics such as the board life cycle, power relationships with and between board and staff, organizational culture, and management/organizational structure are influential on effective board governance. The complexities of these dynamics suggest that one governance approach will not likely create an environment in which boards are successful; rather, changing dynamics require a multifaceted or hybrid model to respond. Effective board governance and effective nonprofit organizations does correlate.

Figure 1 - Bradshaw, Hayday and Armstrong conceptualized governance typology depicts the relationship between four governance models along two axes. The horizontal axis indicates whether the organization governance model supports change and innovation, or whether it is embedded in the status quo; whereas the vertical axis indicates the level of constituent collaboration/engagement (unitary versus pluralistic) (Bradshaw, et al., 2007). The four Governance Models represented are 1) policy governance model; 2) constituency/ representative model; 3) entrepreneurial model; and, 4) emergent cellular model. Figure 2 Bradshaw, Hayday and Armstrong conceptualized governance typology - Force Field Analysis expands the referenced theoretical framework typology to include a defining statement for each representative governance model and to add specific definition to the four 


\section{Macrothink}

forces pulling on P-NFP boards (status quo/change and innovation \& unitary/pluralistic).

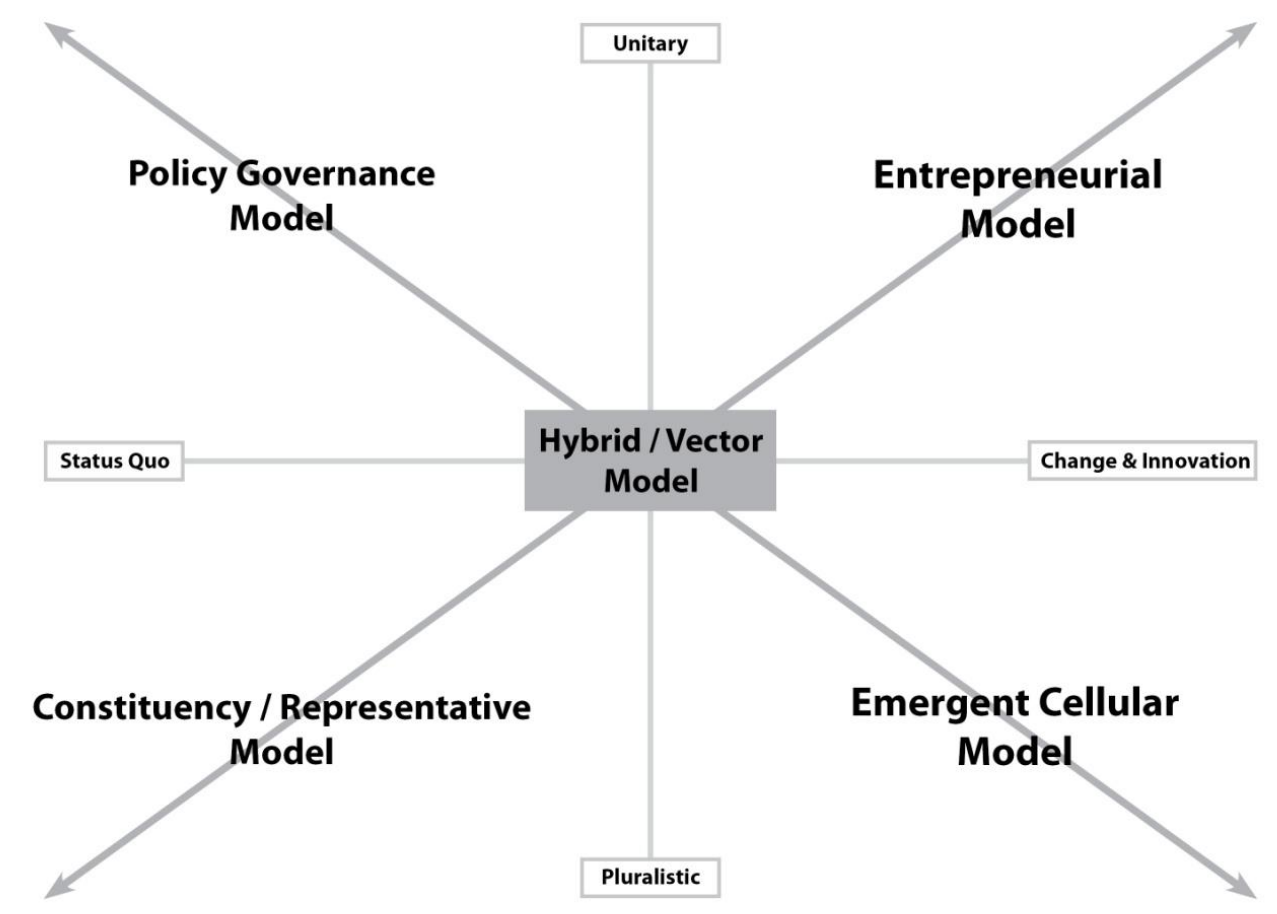

Figure 1. Bradshaw, Hayday and Armstrong conceptualized governance typology.

The new hybrid/vector model of governance recognizes that no one governance model responds to all aspects of complex organizational dynamics and that a truly effective model will respond to various pressures attempting to pull it in one direction or another (Bradshaw, et al., 2007). The concept asserted suggests that forces pulling on the middle vector (called the hybrid/vector model) ultimately influence and define the shape and balance of the organizational governance model and react to dynamics affecting governance. "The Vector Model, as we saw it, was resilient and flexible and demanded constant dancing with the tensions or pulls between competing assumptions and values. It would not get stale or static" (Bradshaw, et al., 2007, p. 15).

Bradshaw, et al. (2007) suggested the following primary functions of the board under the new hybrid/vector governance model:

Outreach:

1. Environmental scanning, monitoring emerging trends, needs, expectations and problems

2. Soliciting input from a broad base of stakeholders through the expanded board meetings Stewardship:

1. Challenging the framework and vision of the organization 


\section{Macrothink}

2. Maintaining a forward looking perspective

3. Ensuring the evolution, capacity and robustness of the organization so it stays organic and does not become solidified

Overseeing of Operational Structure and Operations:

1. Accountability functions

2. Fiduciary responsibility broadly defined

3. Check and balance on operations within a policy governance model

4. Protecting the integrity of the system

5. Holding the tensions between a results orientation and a process orientation

\section{Governance Constructs}

Three governance constructs further contribute to effective governance. They are: 1) focus on providing assurance to constituents; 2) fostering an organization that maintains sustainable balance; and, 3) engaging constituents in a shared governance model.

\subsection{Assurance}

The notion of being responsible for outcomes is rooted in the concepts of accountability and assurance. The difference between the two, however, provides a basis to construct and assess a new governance model that will better meet the needs of boards and constituents. Accountability by definition means the state of being accountable, liable, or answerable for the outcome of a responsibility (Webster's collegiate dictionary, 1989). Assurance means providing confidence, certainty that something will transpire as expected as determined/influenced by a dialogue with stakeholders. Table 1 - Three Public Sector Paradigms (Carr, 2010) demonstrates a shift that has occurred from the Public Administration Paradigm to the Public Management Paradigm during the later years of the twentieth century. The Public Management Paradigm considered data-based decisions, efficiency, sustainability, constituent participation, and cost reduction. The shift to the Public Assurance Paradigm has occurred in some aspects of Public and Not-For-Profit (P-NFP) governance.

The Public Assurance Paradigm increases confidence and certainty that an organization is achieving the desired results and providing the required services by changing the organizational focus (Carr, 2010). The shifts demand a change in how governance boards act and what they focus upon. The shift toward a Public Assurance Paradigm from the Public Management Paradigm is as profound as was the shift from the Public Administration Paradigm. They are transformative and require a fundamental change in governance structures, foci, and methods. 
Table 1

Three Public Sector Paradigms

Three Public Sector Paradigms

\begin{tabular}{|c|c|c|c|}
\hline & $\begin{array}{l}\text { The Public } \\
\text { Administration } \\
\text { Paradigm }\end{array}$ & $\begin{array}{l}\text { The Public } \\
\text { Management } \\
\text { Paradigm }\end{array}$ & $\begin{array}{l}\text { The Public } \\
\text { Assurance } \\
\text { Paradigm }\end{array}$ \\
\hline Needs Assessment & $\begin{array}{l}\text { What programs are } \\
\text { needed, i.e. what } \\
\text { groups funded at } \\
\text { what level? }\end{array}$ & $\begin{array}{l}\text { Who does what, i.e. } \\
\text { what order of } \\
\text { government, what } \\
\text { roles for markets and } \\
\text { communities? }\end{array}$ & $\begin{array}{l}\text { Who gets what, i.e. } \\
\text { allocation of public } \\
\text { goods, e.g. health }\end{array}$ \\
\hline Core Principles & $\begin{array}{l}\text { Impersonality, } \\
\text { uniformity, } \\
\text { universality, i.e. "one } \\
\text { size fits all" }\end{array}$ & $\begin{array}{l}\text { Economy, efficiency, } \\
\text { effectiveness, i.e. } \\
\text { choices, markets, } \\
\text { competition }\end{array}$ & $\begin{array}{l}\text { Equity, } \\
\text { ethical, } \\
\text { accessible, } \\
\text { affordable, } \\
\text { inclusive }\end{array}$ \\
\hline Management Focus & $\begin{array}{l}\text { Inputs, i.e. first order } \\
\text { allocations, e.g. the } \\
\text { envelope system }\end{array}$ & $\begin{array}{l}\text { Output, i.e. first } \\
\text { order results, e.g. } \\
\text { customer services }\end{array}$ & $\begin{array}{l}\text { Outcomes, i.e. } 2^{\text {nd }} \\
\text { order allocations } \\
\text { resulting, e.g. } \\
\text { long-term impact }\end{array}$ \\
\hline Driving Forces & $\begin{array}{l}\text { Manageability, i.e. } \\
\text { effort is contained }\end{array}$ & $\begin{array}{l}\text { Sustainability, i.e. } \\
\text { effort is affordable }\end{array}$ & $\begin{array}{l}\text { Excellence, i.e. } \\
\text { results exceed effort }\end{array}$ \\
\hline $\begin{array}{l}\text { Role of Government } \\
\& \text { Individuals }\end{array}$ & $\begin{array}{l}\text { Welfare state, i.e. } \\
\text { government as doer, } \\
\text { individual } \\
\text { dependent }\end{array}$ & $\begin{array}{l}\text { Government as } \\
\text { broker - individuals } \\
\text { as participants in } \\
\text { policy development } \\
\text { process }\end{array}$ & $\begin{array}{l}\text { Government } \\
\text { guarantor as } \\
\text { individuals } \\
\text { citizens with rights } \\
\text { and responsibilities } \\
\text { in policy } \\
\text { development and } \\
\text { implementation }\end{array}$ \\
\hline Role of Communities & Articulate demands & $\begin{array}{l}\text { Participate in } \\
\text { consultations }\end{array}$ & Shared in governance \\
\hline Focus on People & Program budgeting & Business planning & Risk assessment \\
\hline HR Strategy & Recruit & Outsource & Develop \\
\hline
\end{tabular}




\begin{tabular}{|l|l|l|l|}
\hline & competency & $\begin{array}{l}\text { capital through } \\
\text { learning }\end{array}$ \\
\hline Allocation Strategy & $\begin{array}{l}\text { Allocation } \\
\text { expenditures }\end{array}$ & Reduce costs & Allocate investments \\
\hline
\end{tabular}

\subsection{Sustainable Balance}

Measuring performance within a P-NFP organization is much more difficult than that of a private or public for-profit business. In the private sector, annual profit and return on investment are just two examples of the type of indicators attached to business performance. Assessing the performance (or value) of a P-NFP organization or department without a profit or return orientation is a daunting task generally subject to complex debate, and always seeming to represent individual personal perspective and bias.

Figure 3 - Principle-Based Governance - Sustainable Balance represents the area for which a P-NFP must operate to be a high performing entity (point of intersection). "The point of intersection is called the Trillion and is where sustainable organizations define their success" (McCue \& McCue, 2002, p. 153). The trillion is the point where a P-NFP has achieved sustainable balance between the complex competing dimensions: the stakeholders (constituents), efficiency (inputs, processes, and outputs) and effectiveness (outcomes)(Horswill, 2003). Developing a systematic understanding of the three dimensions will result in organizational thinking at a higher level; a level that will move the organization toward its stated mission, vision, values, and goals.

The sustainable balance construct accepts that certain situations will require a greater orientation to one of the three dimensions and that P-NFPs are, by their very nature, subject to political influence and other external pressures from time to time (Horswill, 2003). However, the organization's response to these pressures is what is most important. They must ensure reconciliation of the competing interests in a way that guarantees the organization is operating within the trillion to maintain focus, order, and resources to achieve their stated purpose. 


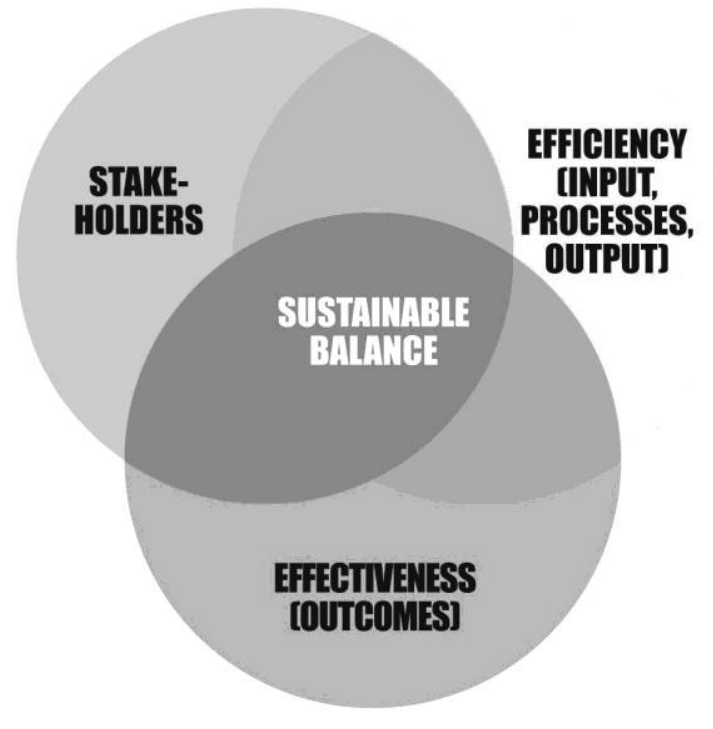

Figure 3. Principle-Based Governance - Sustainable Balance.

\subsection{Shared Governance}

P-NFP organizations have come under pressure to be sustainable during a time when financial and human resources are becoming scarce. Shared governance means "an organization intentionally produces balanced results through a collaborative process which utilizes shared resources consistent with the agreed upon mission and principles" (Inspiring education, 2009, np). Characteristics of a P-NFP organization that can demonstrate shared governance:

1. Shared governance permeates the entire organization affecting all levels of decision-making;

2. Shared governance is not just policy coordination; rather, it means decisions made collectively and that authority, responsibilities, and assurances are held in various combinations;

3. Communication based on consistency, trustworthiness and is multidirectional;

4. Participants in the shared governance process are accountable for the proper execution of their role; and,

5. Some formal structure exists to define the shared governance process and expected outcomes (Inspiring education, 2009, p. 25).

Shared governance requires an internal and external perspective. Internally, it means engaged board members, senior leaders, managers, and staff in a process that strengthens organizational balance. Externally, shared governance attempts to achieve the same outcomes; however, it does so through engaging external parties as partners (Inspiring education, 2009). Understanding who has primary concern for a decision is critical when engaging parties in shared decision-making. Role and mandate confusion is an added complexity to consider when structuring a multi-organizational shared governance process. Defining who should attend, the structure of the committee, and how to select representatives are also important 


\section{Macrothink}

considerations. The external variable adds a layer of complex issues to manage.

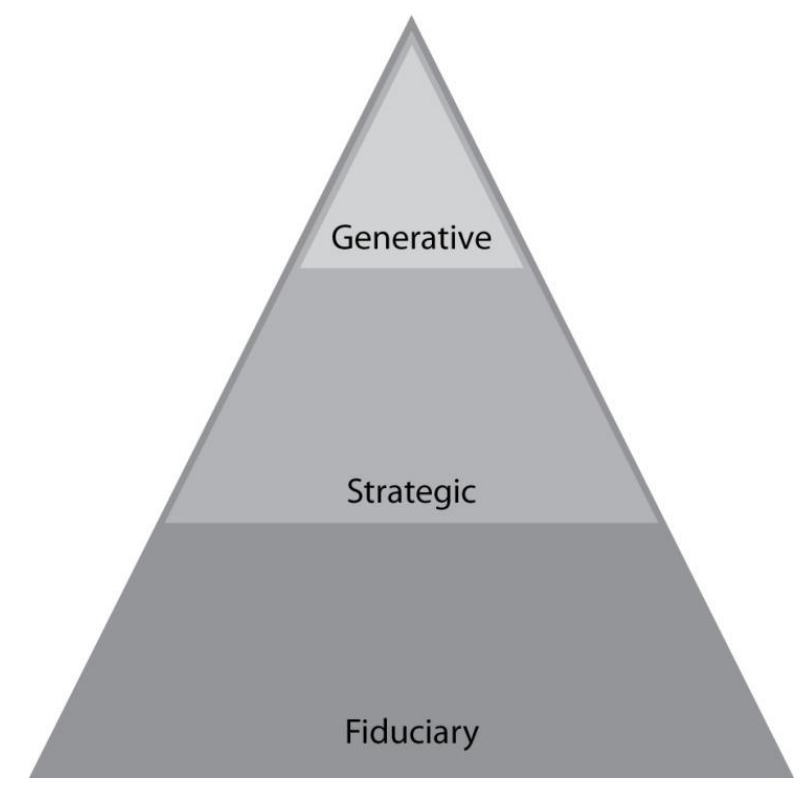

\section{Principle-Based Governance}

\subsection{Governance as Leadership}

Examining leadership of the board requires consideration of three modes from which they perform their work: 1) fiduciary; 2) strategic; and 3) generative (Chait, Ryan, \& Taylor, 2005). In the fiduciary mode, the board fulfills its legal responsibilities of oversight and stewardship. It is critical that any governance model appropriately address this governance mode. Boards make critical decisions pertaining to their strategic plan and operational decisions relating to the organization's business in the strategic mode. In the generative mode, “... [the] board engages in deeper inquiry, exploring root causes, values, optional courses and new ideas" (Chait, et al., 2005, p. 1). Assessing the board's operation based on these three modes provides insight into their fundamental, or instinctive, mode of operations.

Figure 4 - Traditional Governance Focus - Accountability Model demonstrates a board that views their primary role as oversight and stewardship. A large quantity of their work focuses on the fiduciary tasks and less on the strategic mode and even less on the generative mode. A traditional board focused on accountability is generally driven by large quantities of board policy that attempt to guide the organization to pre-conceived decisions based on the values of the board that established the policy. Often there is less opportunity for any form of shared governance and the board focused on inputs, processes, and outputs, rather than advancing the organization into the future. The result of a fiduciary focus is an organization that values

\section{Figure 4. Traditional Governance Focus - Accountability Model.}

compliance as opposed to innovation and performance. "Unfortunately, many boards and executives feel if you are not making decisions, you are not governing. We are saying governing is a set of activities that generates the need for decisions" (Chait, et al., 2005, p. 1). Chait, et al., further stated that the fiduciary mode “...create[s] procedural accountability ... 


\section{Macrothink}

put[ing] huge emphasis on compliance rather than on performance" (Chait, et al., 2005, p. 2).

Figure 5 - Principle-Based Governance Focus - Assurance Model displays how a board operates when the primary focus is on representation of constituents through generative dialogue with an equal degree of focus on the strategic issues (Chait, et al., 2005). Chair, et al. stated "Generative work conveys the gift of helping executives see things better, improving their perception and perspective so that they are in a better position to invent new goals, to discard old goals, to better see problems and to discard problems that really are not that important in the long run" (p. 2). Governors and the CEO operate in concert with each other when exploring constituent's expectations. Boards that operate with a principle-based governance (assurance) focus can affect decisions that achieve sustainable balance, engaged constituents in a manner that results in high degrees of collaboration, establish structures with definition of roles and responsibility, create high constituent satisfaction and trust, and fully address their fiduciary responsibilities.

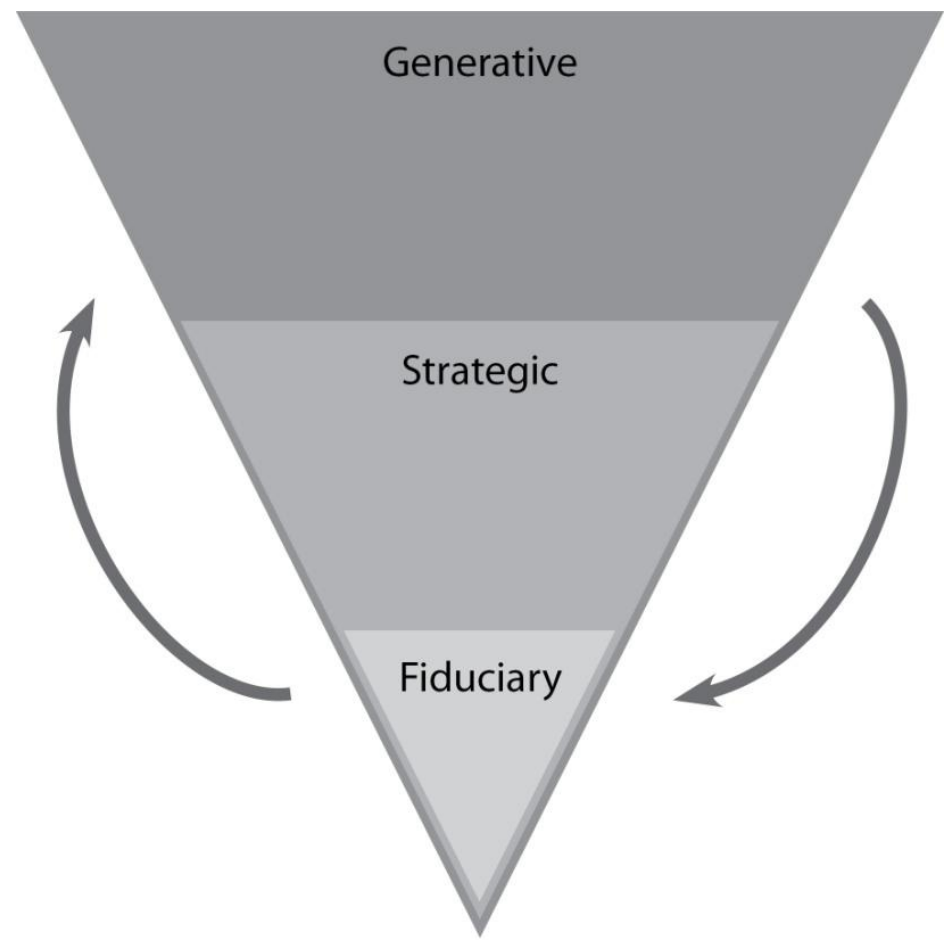

Figure 5. Principle-Based Governance Focus - Assurance Model.

\subsection{Governance Structure}

A Public and Not-For-Profit (P-NFP) board operating under the Principle-Based Governance Model (Assurance) must define, through structural policies, the role of the board and delegated authority to administration through the CEO. This delegation of authority defines, by its very nature, the involvement of the board in certain activities. Five key influential documents exist in the Principle-Based Governance Model (Assurance) that provides the necessary structure for the board to fulfill its mandate; they are 1) board mission statement; 2) universal guiding principles; 3) board policies; 4) operational principles; and 5) 


\section{A. Macrothink}

administrative procedures. Figure 6 - Principles-Based Governance - Basic Structure depicts the five influential documents along with the board's operational involvement. The governance area is strictly the responsibility of the board, whereas the delegated area is the primary responsibility of the CEO. The collaborative section ties together the board and CEO to support understanding and mutual commitment. The board is less involved but not fully removed in developing the collaborative and delegated documents.

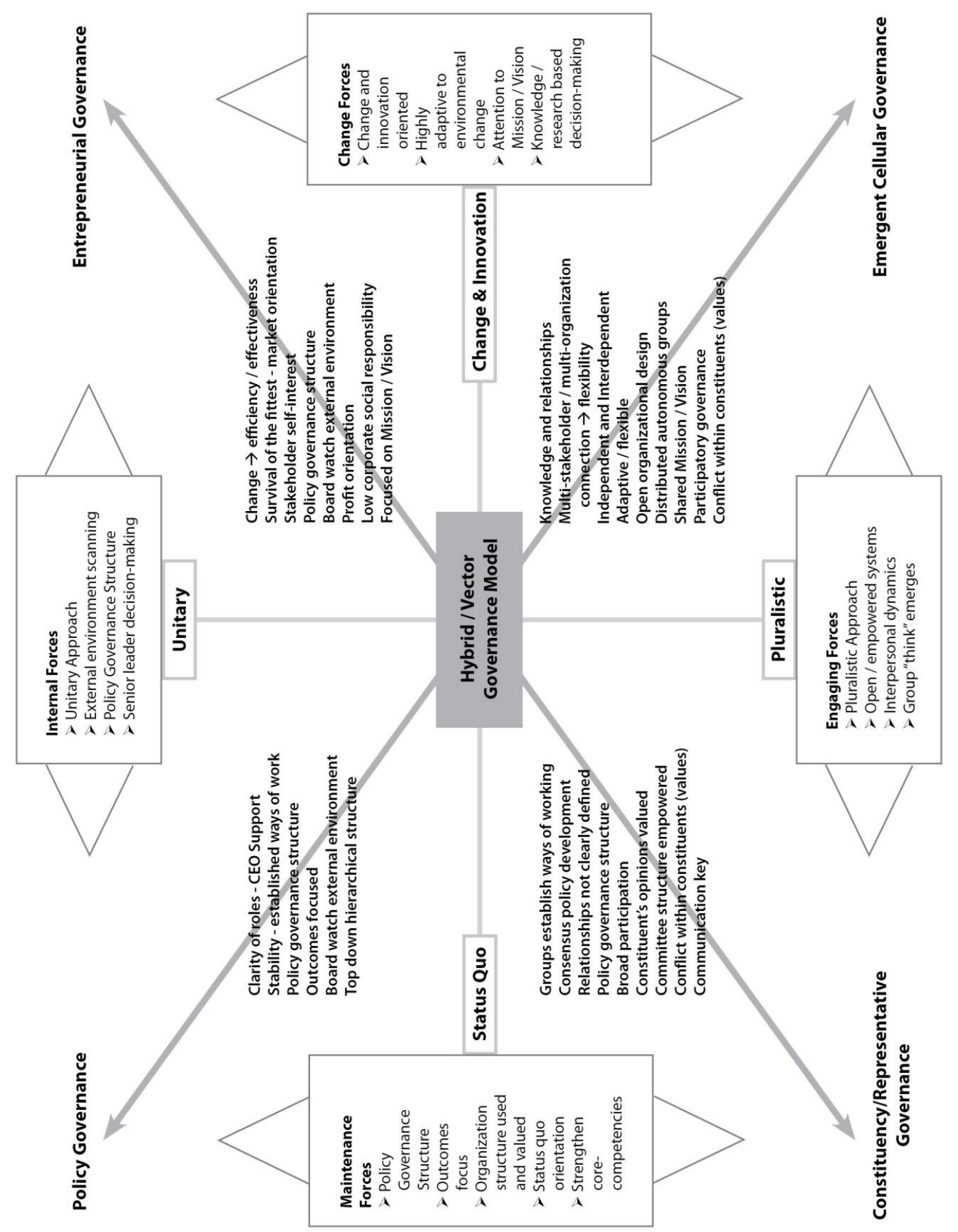

Figure 2. Bradshaw, et al., conceptualized governance typology - Force Field Analysis 
Ambassadorial and Legitimating:

1. Promotion of the organization to the external communities based on the vision of the system

2. Ensuring the interests of a broad network of stakeholders are represented

3. Board members lend their positional, professional and personal credibility to the organization through their position on the board

Self Reflection and Assessment:

2. Regular reviews of the functions and effectiveness of the board itself

3. Assessing the level of trust within the board and the quality of the group process (p.17/18).

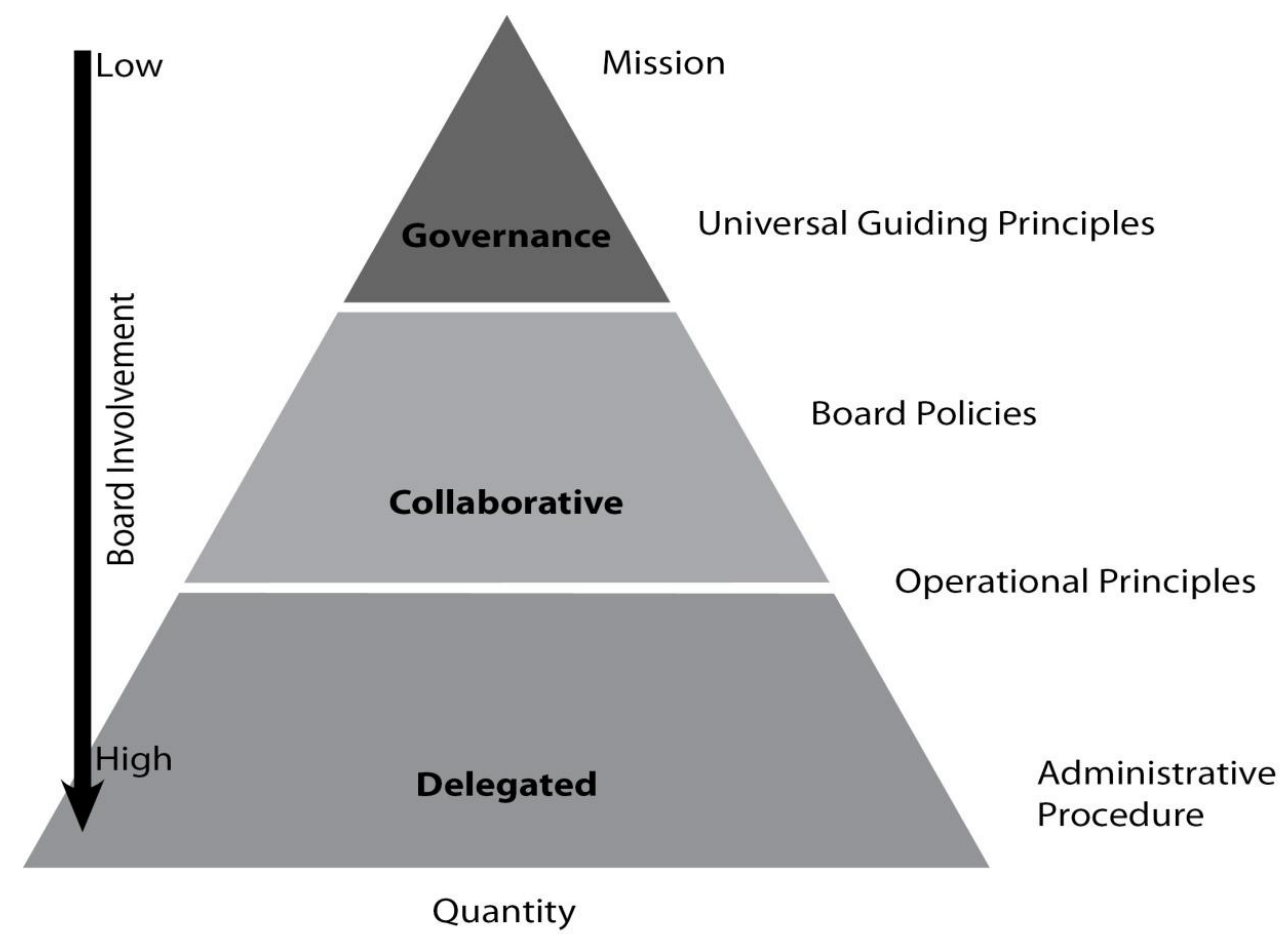

Figure 6. Principles-Based Governance - Basic Structure.

The five documents utilized in the Principle-Based Governance Model (Assurance) have some common application to other governance structures. There are unique applications within this model. The following definitions apply:

1. Mission - includes the creation of a mission (purpose) and vision (future) statement for the organization. The statements represent constituents' expectations and values relating to the P-NFP organization's mandate.

2. Universal Guiding Principles - these Universal Guiding Principles (UGP) are enabling principles that will support the CEO and staff in working toward fulfilling the assurance 
of the system. Derived substantially from dialogue with constituents, they provide the framework and parameters for decision-making. Presented in the form of questions expecting a "yes" answer, they get to the fundamental core values and beliefs of the board.

3. Board Policy - focus primarily on governance operations and the delegation of responsibility to the CEO. The board develops limited policies that influence system activities in key areas deemed necessary to fulfill its mandate. Certain legislation requires boards to have specific policies.

4. Operating Guiding Principles - support the UGP and establish statements to achieve the desired results. These principles must be congruent with the mission and UGPs. Presented as statements-of-fact, they are specific statements relating to various operational domains that establish given outcomes. Board developed in collaboration with system leaders to ensure understanding, and to develop mutual commitment. Statement ultimately enacted through formal board policy.

5. Administrative Procedures - strategic directives and systematic expectations established by the CEO on key topics requiring standardized processes or outcomes. Board informed of administrative procedures; however, primary responsibility rests with the CEO.

At the core of the Principle-Based Governance Model (Assurance) is the construct that organizations must maintain sustainable balance to fulfill their stated mandate. Figure 7 Principle-Based Governance - Systematic Approach depicts the basic structure in the form of a continuous improvement cycle. The three areas of the basic structure (governance, collaboration, and delegation) surround the trillion (sustainable balance). The bottom left area is characterized as Board Governance (Direct Control), the bottom right Guiding the System (Shared Influence), and the top as Administrative Empowerment (Delegated Authority).

\subsubsection{Board Governance (Direct Control)}

The board maintains direct control to establish the mission/vision, to establish the UGPs, and to develop a shared governance approach appropriate for the organization that meets the needs of constituents (see Figure 8). This section of the governance model establishes a framework from which good business practice and morally good practice join (Liedtka, 1998). A governance model designed to create system assurance must instill confidence in how constituents' perceive their actions, by aligning ethical behavior and organizational activity across all levels of the organization. 


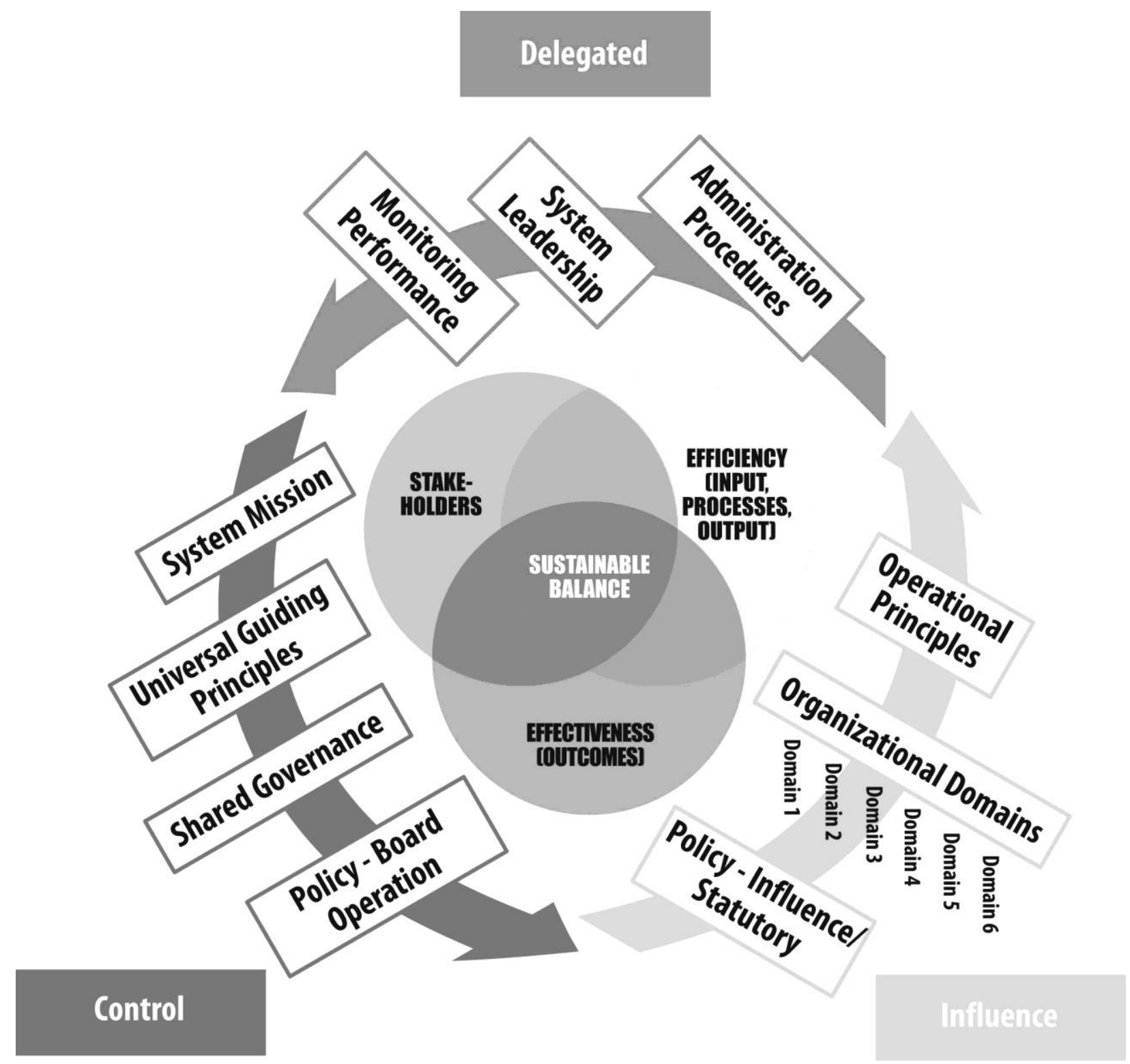

Figure 7. Principle-Based Governance - Systematic Approach. 


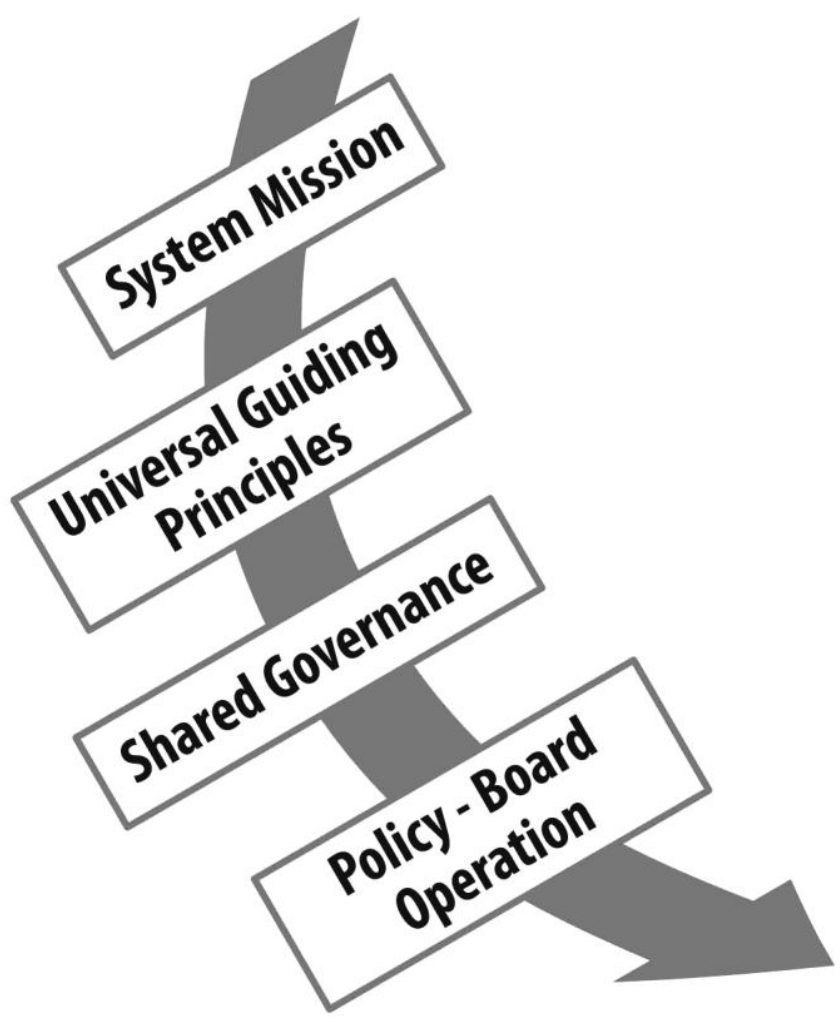

Figure 8. Principle-Based Governance - Board Governance

(Direct Control)

System Mission. Many organizations publish a mission, vision, and corporate motto to distinguish their business from other businesses competing for market share. A slick motto can improve customer product recognition and can increase product demand and by extension, profits (Palepu, Healy, \& Bernard, 2004). For a P-NFP organization, however, "the mission is aligned with the legislative mandate of the organization (sic) and will dictate the measures of success" (Marin, 2012, p. 117). Legislative mandate can be enactments of governments or the purpose statement contained in a P-NFP constitution and bylaw. The key factor is that for P-NFP organizations, achieving the mission is the primary goal of the organization. P-NFP organizations exist generally to provide direct services to customers.

At a strategic level, organizations must understand in absolute terms why they are in business and what success looks like. Kaplan and Norton (2008) stated, "Before formulating a strategy, managers need to agree on their company's purpose (mission), its aspiration for future results (vision), and the internal compass that will guide its actions (values)" (p. 64). The mission offers to customers and clients an understanding of why the organization exists. This knowledge provided a basis from which constituents develop a need to engage with the P-NFP. The mission creates the bridge that links together the organization and those that they serve. The strategic planning process captures the organization vision and core values, and beliefs of the board. Articulation is defined through the universal guiding and operational principles.

Universal Guiding Principles. Universal Guiding Principles (UGP) questions are enabling principles that will support the CEO and staff in working toward fulfilling the assurance of the system. They provide the framework and parameters for decision-making. The board 
maintains control to establish the UGPs, dialogue with constituents helps to inform them. UGPs are by their very nature high-level constructs that represent the core values and beliefs of the board. The construction of UGPs is through careful considerations and definition of the board's core values and beliefs. The presentation of UGPs is in the form of all questions expecting a "yes" answer.

Rotary International has maintained UGPs called the four-way test. All decisions made throughout the organizational structure are to consider the following four questions: 1) Is it the TRUTH?; 2) Is it FAIR to all concerned?; 3) Will it build GOODWILL and BETTER FRIENDSHIPS?; and, 4) Will it be BENEFICIAL to all concerned? (Rotary International, 2012; Warren, 2011). This example demonstrates that boards can state in a precise way their core values and beliefs, and affect decisions within the organization. From Rotary International's perspective, they desire to be truthful, fair, build goodwill, better friendships, and make decisions that benefit everyone affected by the decision. Without complex policies directing organizational decisions, Rotary International provides guidance from an ethical position of strength.

All corporate governance boards, either public or private must concern themselves with how managers are dealing with ethical decisions (Jones, 2007). Are there ethical guidelines available to support decision-making? Are there clear processes to follow when faced with an ethical dilemma? Jones (2007) stated, "The essential problem in dealing with ethical issues, and thus solving moral dilemmas, is that there are no absolute or indisputable rules or principles that can be developed to decide if an action is ethical or unethical" (p. 42). UGPs allow boards to establish a decision-making barometer to help managers understand when ethical decisions, and the resulting actions, fall within acceptable boundaries established by the board. When UGPs capture the primary core values of a board, and processes are put in place to ensure and monitor that managers are acting in accordance with the principles, boards can have some assurance the resolution of ethical dilemmas is congruence with expectations.

Strategic Planning. A primary tool available to boards to guide the direction of the organization is through the development of a strategic plan (Lipman, 2007). The strategic plan provides a mechanism from which the board can gauge growth toward defined targets and from which to measure management's implementation effectiveness. "The real value of strategic planning is not primarily in the final plan, but more in the intellectual journey that the participants take in exploring the future. This often sensitizes them to future possibilities that they had not been aware of. It also helps them prepare to shape that future" (Blatstein, 2012, p. 34).

A properly developed strategic planning process would create a pluralistic approach and strive for change and innovation, as indicated in Bradshaw, et al. (2007) conceptualized governance typology (see Figure 1). The board should undertake a strategic planning process that reinforces a shared governance commitment and provides the board an opportunity to engage its constituents in a meaningful and productive manner. Most boards for P-NFP organizations, elected or appointed, represent a certain defined constituency. The actions of the board to engage the constituency in the strategic planning process helps to ensure the strategic direction of the organization is both representative and congruent with values and 
expectations.

There are many forms and structures from which to conduct a strategic plan. Some are complex and very detailed, whereas others are simple and high-level by design. Whatever strategic planning process is undertaken, what is important is that certain key assessments occur and that final strategic directives guide future action. The process should assess the current organization's environment by using a SWOT (strengths, weaknesses, opportunity, and threat) or COGS (challenges, opportunities, gaps, and strengths) analytical tool. The analysis should include a process to understand and celebrate existing success from which the strategic plan can build upon. Finally, it should engage the board and constituents in a discussion about the preferred future for the organization. These all culminate into a deep understanding of, and provide a basis for, the final strategic directives which will guide the board and senior administration during the term of the strategic plan.

Shared Governance. Rooted in the generative work posited by Chair, et al. (2005) is the notion that board members can engage effectively their constituents in a generative discussion in ways that informs the organization with critical information to achieve sustainable balance. Generative dialogue requires a fundamental shift in how board members approach the process of engaging their constituents - do the process wrong, and little value is garnered from the engagement.

P-NFP boards should view generative dialogue as the main strategy to achieve shared governance. The basic governance model contained in Figure 6 - Principles-Based Governance - Basic Structure depicts the level of involvement by the Board in various activities, and Figure 5 - Principle-Based Governance Focus - Assurance Model suggest that effective boards remain focused on strategic and generative work. These two figures link the critical alignment between those who lead by doing and those who lead by representing. Boards that can engage their constituents in a generative dialogue, and subsequently represent the results of the dialogue in various leadership opportunities will maintain a system that has the potential to achieve sustainable balance.

Board Policy Manual. The Policy Governance Model posited by John Carver in 1990 establishes a board policy manual around end, executive limitations, board-CEO relationships, and governing process policies (Bradshaw, et al., 2007). The ends policy establish the goals and outcomes of the organization, the executive limitations policy establishes the boundaries that the CEO must operate within, the board-CEO relationships policy address maters of communication and evaluations, and finally the governing process policy places structure around how the board will operate. Research has suggested that boards who have implemented the Carver Governance Model feel disconnected from programs and operations, which have caused staff to have less trust in the board.

The Principle-Based Governance Model (Assurance) fundamentally supports the structure of the Carver Governance Model. It does not envision large quantities of policy directing the $\mathrm{CEO}$ on how to conduct business and that the board requires policies to influence their own actions as a corporate governance body. However, policies can exist to direct operations in a positive manner - not limiting the board to negative worded limitation policies as defined by Carver. Boards would develop policies in four key areas designed to provide leadership and direction to the organization. They are 1) board operations; 2) management relationships; 3) 
system influence; and 4) statutory compliance. The first two fall within the Board Governance (Direct Control) realm, and the last two within the Guiding the System (Shared Influence) realm.

1. Board Operations policies focus on how the board will operate as a corporate body. The primary policy in the section is the "mission, vision and guiding principles" policy that articulates the board's mission, vision, universal guiding principles, and operating principle statements. Other policies include: 1) board member rights and responsibilities; 2) committees of the board; 3) role of the board; 4) conflict of interest; 5) board member code of conduct; 6) monitoring performance; and 7) whistle-blowing protection.

2. Management Relationship policies focus on defining in clear terms the relationship the board intends to have with management. This definition provides the necessary structure to succeed and allows management to have "...clear understanding of the types of decisions which can be made by management without board approval and those which require board approval" (Lipman, 2007, p. 316). Policies would include: 1) delegation of authority; 2) management role and responsibilities; 3) financial management; and, 4) CEO evaluation.

Board Committee Structure. Traditionally, the structure of board committees focuses on the organizations core purpose. Standing committees established in organizational bylaws may include finance, labor relations, policy, appeals, ethics, and other committees specific and unique to the business requirements. These committees have terms of reference stating the board delegated mandate and any decision/reporting requirements. When discussing committee structure and effect, Bradshaw, et al. (2007) stated, "[committees] can lead to organizational rigidity, top-down control and the loss of the ability to adapt and respond quickly to environmental shifts and changes" (p. 12). Applied to the Theoretical Framework sited herein, traditional committee structures would tend to support unitary involvement and maintaining the status quo.

The board committee structure contained in the Principle-Based Governance Model (Assurance) requires a new structure and committee purpose. As depicted in Figure 6 Principles-Based Governance - Basic Structure the board's primary role is to focus its efforts on governance matters with some effort toward engaging collaboration while putting very little effort into the delegated realm. To achieve this revised focus, boards must modify their committee structures. Largely, the Principle-Based Governance Model (Assurance) shifts the structure and orientation of board committees from doer/decision-making to that of leader/monitor. The shift creates a fundamental change in how P-NFP boards view committees. First, the entire board engages in activities of the board, not just a select few who happen to have an appointment by the chair to a committee. Second, the opportunity to misdirect administration reduces as all board members engage in critical discussions. Finally, board members understand that their committee work is helping to advance the organization in a way that aligns with their beliefs and values and not to play interfere with management. While no single listing of committees exists that would apply to all P-NFP boards, it is likely the board would create a high-level labor committee, an audit committee to monitor financial matters, and likely, an advocacy committee. A P-NFP board may also need to create board 


\section{Macrothink}

committees to comply with their regulatory environment. Committees established by boards should focus on being governance leaders and monitoring assurance.

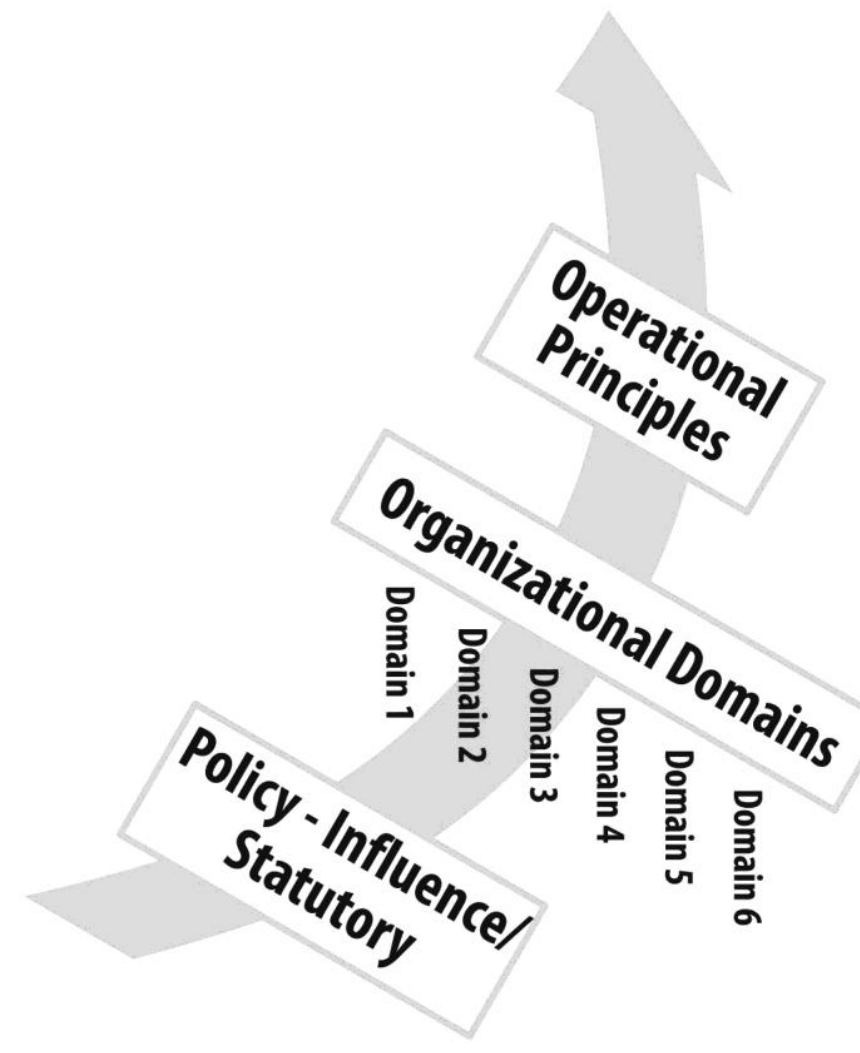

Figure 9. Principle-Based Governance - Guiding the System

(Shared Influence).

\subsubsection{Guiding the System (Shared Influence)}

Guiding the System (Shared Influence) creates a pluralistic environment for the board to engage constituents in a dialogue about the system expectations. The system guidance created in this realm offers the CEO, staff at all levels, and constituents an opportunity to explore the board's key policy - mission, vision and guiding principles - from an operational perspective. Figure 9 - Principle-Based Governance - Guiding the System (Shared Influence) depicts the components of this realm.

Board Policy - Influencing Outcomes. Policies developed in the Guiding the System (Shared Influence) realm complement the board work in the Board Governance (Direct Control) realm, whereby policies and systems implemented ensure the values and beliefs of the board are driving complex system decisions. Policies in this realm focus on key strategic directives that the board, in dialogue with the system, determine are required. The two types of policies are:

1. $\quad$ System Influence - The Principle-Based Governance Model (Assurance) respects 
the need for boards to provide clear direction in a few areas seen as critical to the organization's success. A limited number of policies provide the board the opportunity to clarify the intent of their primary policy (mission, vision, and guiding principle policy). System influence policies help to engage the board in the overall direction of the organization, without overly influencing the organization through excessive policy statements. System influence policies should be of such importance to the board that they include them as criteria in the board annual evaluation.

2. $\quad$ Statutory Compliance - All organizations have legislative structure enacted by various regulatory bodies. While it is redundant to restate laws in organizational policies, it is important to support those enactments to ensure compliance with both the written word and the spirit of the law. Doing so creates an environment for ethical decision-making contextual to the organizations cultural values (Payne, Raiborn, \& Askvik., 1997). It is impossible to state a standard set of policies to address each organization's unique regulatory environment. It is important that each organization identify those policies the board feels it needs to make a statement to ensure operations align appropriately with the regulatory environment.

Organizational Domains. Each P-NFP organization can identify unique organizational domains. These domains may come from hierarchical structures or from interdependent functional teams focused on the organization's mission. The identification of domains allows the board, through generative dialogue, to create statements-of-fact on outcome expectations. There is no wrong answer to this classification process. The goal is to group the activities of the organization into domain categories to facilitate development of operating principle statements-of-fact.

Operating Principles. The development of operating principles for the organizational domains listed expands further the core value and belief statements captured in the UGPs. The UGPs require a "yes" answer; however, they provide little direction or definition of what constitutes an acceptable solution. The operating principles must complement UGPs questions. By doing so, they increase board confidence that the spirit of the UGPs is being applied.

Senior management and other leaders who face complex, difficult or ethical decisions can find comfort and direction with the UGPs and the operating principles. Ibarra-Colado, Clegg, Rhodes, and Kornberger (2006) postulated that the complex interaction between individual morality and organizationally prescribed principles ultimately determines ethical conduct. Accepting this assertion reinforces the need for P-NFP boards to prescribe clearly their organizational principles, which is done through the UGPs, operating principles, and any system influence policies developed.

\subsubsection{Administrative Empowerment (Delegated Authority)}

The Administrative Empowerment (Delegated Authority) realm of the Principle-Based Governance Model (Assurance) recognizes the board must empower the system and delegate authority through the CEO while assuring constituents that the services provided are necessary and the desired results achieved. Figure 10 - Principle-Based Governance Administrative Empowerment (Delegated Authority) depicts the three key components of this 


\section{Macrothink}

realm.

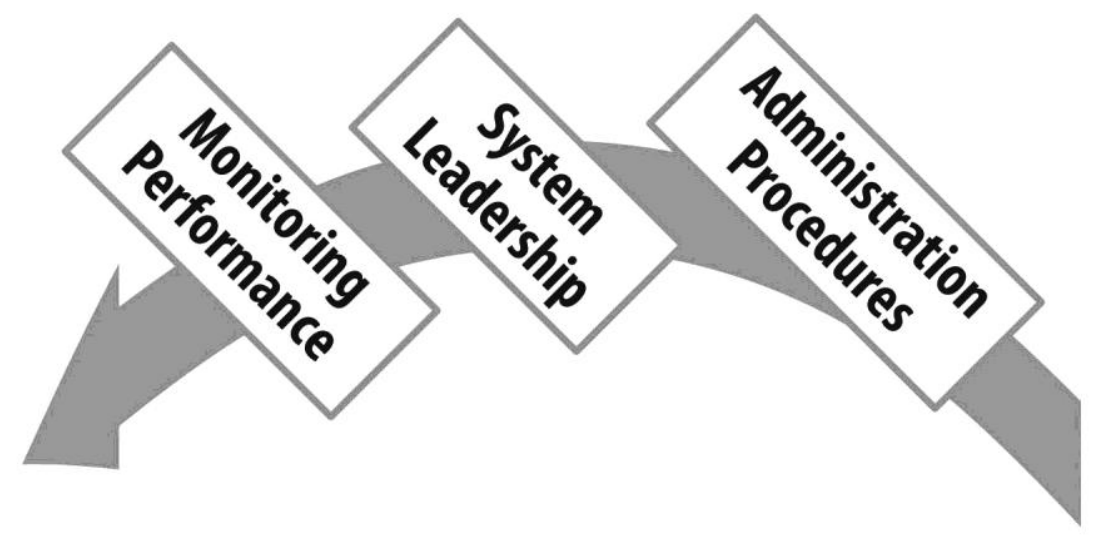

Figure 10. Principle-Based Governance - Administrative Empowerment

(Delegated Authority).

Administrative Procedures (CEO Influence). Administrative procedures are strategic directives and systematic expectations established by the CEO on key topics requiring standardized processes or defined outcomes. While primary responsibility rests with the CEO to establish and maintain the administrative procedures, the board remains informed fully of the context, purpose, and effectiveness of any administrative procedure developed.

Figure 6-Principle-Based Governance - Basic Structure depicts that there is a large quantity of administrative procedures compared to the number of board policies. Additionally, the board has a low involvement in the development and maintenance of the administrative procedures. It is critical that the board understand the content of the administrative procedures to ensure they are fully congruent with board policies. To achieve this, boards should ensure that the delegation of authority policy contain a requirement that includes the circulation of any administrative procedures developed or changed by the CEO. Circulation should occur prior to implementation. The Guiding the System (Shared Influence) realm provides that boards create operational principles statements-of-fact for organizational domains (see Figure 9). Organizing administrative procedures by the same domain assists with ensuring congruence between board established policies and CEO established administrative procedures.

Board members may have a legitimate need to influence the content of an administrative procedure even though they are the responsibility of the CEO. The corporate board should be the body that asserts influence on administrative procedures, not individual board members. To achieve this, board members need an opportunity to raise the content of an administrative procedure to the board table to discuss any assertions they wish to make. The delegation of authority policy should contain direction to the CEO on how the board wishes to implement this opportunity. It is critical to ensure board members provide input or seek clarification through this process and not usurp authority delegated to the CEO.

System Leadership. The CEO and cast of supporting leaders affect greatly the efficacy of the board. In the Principle-Based Governance Model (Assurance), leadership is a shared commitment between board members, senior administrative staff, system staff, and 
constituents who make decisions and constituents engaged in shared governance. "Effective leaders recognize (sic) that it is the combination of human behaviours (sic) and the structures and systems in which they operate that creates a culture that inspires the delivery of good [service]" (Bassett \& Westmore, 2012, p. 18). Boards must consider effective system leadership. It is critical that an assessment of a leader's personal traits occur as well as the organizational structure/systems put in place. Boards should understand the nature of leadership within the organization and be able to articulate how the structures and systems put in place are affecting its overall success.

Effective system leadership is contextual to each organization and research suggests that an effective leader demonstrates numerous characteristics, depending on the situation (Smith, Montagno, \& Kuzmenko, 2004). Boards need to understand the nature of leadership that exists within the P-NFP organization. What is the CEOs predominant leadership style? Does the board as a corporate body portray a dominate leadership style? Are the leaders effective with the followers? Are there indications that transactional leadership is dominant or used inappropriately? Research has not been able to state emphatically that one leadership style is best in all situations (Smith, et al., 2004). However, it is possible to assess the effectiveness of a given style in a specific situation, and boards should be cognizant of the leadership style effect. Kouzes (2003) posited that in organizations who get extraordinary things done, their leaders demonstrate five practices of exemplary leadership; they: 1) model the way; 2) inspire a shared vision; 3) challenge the process; 4) enable others to act; and 5) encourage the heart.

Monitoring Performance. The CEO is ultimately responsible to the board for the actions and outcomes of the organization. The evaluation method utilized by the board to assess the performance of the CEO must recognize and reinforce this fact. Evaluating the CEO's performance must focus on the board defined system expectation (sustainable balance) and overall compliance with board policy. Similar to the Carver Governance Model, the Principle-Based Governance Model (Assurance) attempts to empower the CEO with a supportive, strategic board; however, it does so by avoiding the pitfalls of purely policy driven boards (Bradshaw, et al., 2007).

Monitoring performance, however, is not limited to the board evaluating the CEO on an annual basis. The board must also hold themselves accountable for their performance. The board has varying degrees of responsibility within the governance model. In the Board Governance (Direct Control) realm, the board must hold themselves fully accountable for these outcomes, as they are ultimately responsible. They must also assess their performance in the Guiding the System (Shared Influence) and Administrative Empowerment (Delegated Authority) realms as to varying degrees they are contributory to system outcomes.

The Public Assurance Paradigm increases confidence and certainty that an organization is achieving the desired results and providing the required services by changing the organizational focus (Carr, 2010). Table 1 - Three Public Sector Paradigms summarized the change in perspective required to shift from the Public Administration and Public Management paradigm to the Public Assurance paradigm. If an organization functions within the Public Assurance paradigm, they must be able to assess and report openly their performance compared to established benchmarks and statements of growth. When 
discussing the new paradigm of organization design and systems, Clawson (2009) stated:

[Organizations] will implement "spherical" performance evaluations (that go beyond the groundbreaking 360-degree evaluations done in some companies now) done by team members, subordinates and customers, and suppliers and community citizens, rather than single superior officers. These spherical evaluations will include relevant data from all who have a stake in a person's or a team's contributions to the organization. (p. 59)

The spherical performance evaluations posited by Clawson would involve members of the senior administrative team, board members themselves, a select group of key constituents, and any other person or entity that the board and CEO believe could help assess overall performance.

\section{Conclusion}

The theoretical framework incorporated into this paper originates from the work Bradshaw, Hayday and Armstrong (2007) published on nonprofit governance models, wherein they conceptualized a governance typology that recognized the forces pulling on Public and Not-For-Profit (P-NFP) boards. These forces either reinforce status quo operations or promote change and innovation, and they create an environment either unitary or pluralistic. Figure 1 - Bradshaw, Hayday and Armstrong conceptualized governance typology shows graphically the four forces and how they relate to the four representative governance models (policy, constituency / representative, entrepreneurial, and emergent cellular). The Force Field Analysis contained in Figure 2 is supplemental to Bradshaw et al. work contained in the theoretical framework. The specific definitions create the construct to determine if the Principle-Based Governance Model (Assurance) achieves a hybrid/vector governance model as defined.

\subsection{Assessing the Model}

Two approaches exist from which to assess the Principle-Based Governance Model (Assurance) against the Vector/Hybrid Governance Model posited by Bradshaw et al., (2007). First, by applying the model to the Bradshaw et al., (2007) conceptualized governance typology (including the force field analysis), and second by applying the stated primary functions of a hybrid/vector governance board.

\subsubsection{Conceptualized Governance Typology}

Applying the Force Field Analysis added to the conceptualized governance typology (see Figure 2) provides definition to determine if the Principle-Based Governance Model (Assurance) represents by definition a fully functioning hybrid/vector governance model. To achieve fully the status of a hybrid/vector governance model, the Principle-Based Governance Model (Assurance) must demonstrate, in a practical sense, it can manage the four forces at play and be able to maintain attention to sustainable balance - the core of the governance model.

Maintenance Forces - The Principle-Based Governance Model (Assurance) by design 
maintains the positive effects of a policy governance model. The monitoring performance and delegation of responsibility policies create necessary structures and systems that are oriented toward outcomes. By focusing on the P-NFP mission (which includes vision), important services that are currently provided are maintained. The board's primary policy mission, vision and guiding principles establish system expectations.

Internal Forces - Through the application of the policy governance systems, board members focus energy on monitoring the external environment. This is done through the strategic planning process and engaging constituents in generative dialogue. The delegation of authority policy empowers the CEO to make important decisions and to establish administrative procedures required to achieve the board goals. Delegating authority allows the CEO to act when needed and to engage internal and external constituents when appropriate. The system is not bound by an expectation that constituents will be engaged in dialogue for all decisions; rather, dialogue occurs through the board at the governance level.

Change Forces - The structure supports change and innovation by avoiding excessive board policies that attempt to control the CEO decision-making capacity. Dialogue with constituents creates a responsive environment on emerging issues. Through the work to develop and implement a strategic plan, which includes high constituent consultation/collaboration, the governance model creates an opportunity for a responsive vision. Valuing knowledge and research is achieved through discussions relating to sustainable balance, the Public Assurance Paradigm, and board committee work.

Engaging Forces - At the core of the governance model is the achievement of sustainable balance. One of the three components of sustainable balance is to understand and represent constituent's evolving needs and to assure system decisions will reflect their reality. Through shared governance strategies that incorporate generative dialogue opportunities, the P-NFP board can maintain a pluralistic approach. The Delegation of Authority (CEO Influence) realm creates an open, empowered system to act. The group dynamics created because of the engaging forces needs to be managed to ensure the greatest level of input is received from the constituents.

\subsubsection{Hybrid/Vector Governance Board.}

Bradshaw, et al., (2007) provided specific primary functions of a hybrid/vector governance board. Table 2 - Bradshaw et al., (2007) - Primary function of a hybrid/vector governance board captures the primary functions of a hybrid board and indicates the applicable component of the Principle-Based Governance Model (Assurance). From a purely functional orientation, it is asserted the governance model posited herein does address fully the primary functions of a hybrid/vector governance model. 
Table 2

Bradshaw et al., (2007) - Primary function of a hybrid/vector governance board

\begin{tabular}{|c|c|}
\hline Primary Function & Applicable Model Components \\
\hline $\begin{array}{l}\text { Outreach } \\
\text { Environmental scanning, monitoring } \\
\text { emerging trends, needs, expectations } \\
\text { and problems }\end{array}$ & $\begin{array}{l}\text { Shared governance (generative dialogue) } \\
\text { Strategic planning } \\
\text { Board committee structure }\end{array}$ \\
\hline $\begin{array}{l}\text { Soliciting input from a broad base of } \\
\text { stakeholders through the expanded } \\
\text { board meetings }\end{array}$ & $\begin{array}{l}\text { Shared governance (generative dialogue) } \\
\text { Revised board meeting structure }\end{array}$ \\
\hline $\begin{array}{l}\text { Stewardship } \\
\text { Challenging the framework and vision of } \\
\text { the organization }\end{array}$ & $\begin{array}{l}\text { Mission and guiding principles policy } \\
\text { Strategic planning } \\
\text { Board policy - system influence }\end{array}$ \\
\hline Maintaining a forward looking perspective & $\begin{array}{l}\text { Shared governance (generative dialogue) } \\
\text { Strategic planning } \\
\text { Public assurance paradigm }\end{array}$ \\
\hline $\begin{array}{l}\text { Ensuring the evolution, capacity and } \\
\text { robustness of the organization so it } \\
\text { stays organic and does not become } \\
\text { solidified }\end{array}$ & $\begin{array}{l}\text { Policy governance structure } \\
\text { Board/system evaluation } \\
\text { Leadership capacity/development }\end{array}$ \\
\hline Overseeing of Operational Structure and & Board policy (operations, management \\
\hline$\frac{\text { Operations }}{\text { Accountability functions }}$ & $\begin{array}{l}\quad \text { relationship, and statutory compliance) } \\
\text { Board committee structure (audit committee) } \\
\text { Self evaluation and external reporting }\end{array}$ \\
\hline Fiduciary responsibility broadly defined & $\begin{array}{l}\text { Audit committee } \\
\text { Board/CEO annual work plan (fiduciary) }\end{array}$ \\
\hline $\begin{array}{l}\text { Check and balance on operations within a } \\
\text { policy governance model }\end{array}$ & $\begin{array}{l}\text { Board/CEO annual work plan (fiduciary) } \\
\text { Defined reporting structure (delegation of } \\
\quad \text { authority policy) } \\
\text { Board policy - CEO evaluation }\end{array}$ \\
\hline Protecting the integrity of the system & $\begin{array}{l}\text { Monitoring sustainable balance and } \\
\text { application of Mission and guiding } \\
\text { principles policy } \\
\text { Shared governance (generative dialogue) }\end{array}$ \\
\hline $\begin{array}{l}\text { Holding the tensions between a results } \\
\text { orientation and a process orientation }\end{array}$ & $\begin{array}{l}\text { Monitoring sustainable balance and } \\
\text { application of Mission and guiding } \\
\text { principles policy } \\
\text { Strategic planning }\end{array}$ \\
\hline $\begin{array}{l}\text { Ambassadorial and Legitimating } \\
\text { Promotion of the organization to the } \\
\text { external communities based on the } \\
\text { vision of the system }\end{array}$ & $\begin{array}{l}\text { Shared governance (generative dialogue) } \\
\text { Self evaluation and external reporting } \\
\text { Mission and guiding principles policy } \\
\text { Committee structure - advocacy }\end{array}$ \\
\hline
\end{tabular}




\begin{tabular}{|c|l|}
\hline $\begin{array}{c}\text { Ensuring the interests of a broad network } \\
\text { of stakeholders are represented }\end{array}$ & $\begin{array}{l}\text { Shared governance (generative dialogue) } \\
\text { Committee structure } \\
\text { Self evaluation and external reporting }\end{array}$ \\
\hline $\begin{array}{r}\text { Board members lend their positional, } \\
\text { professional and personal credibility to } \\
\text { the organization through their position } \\
\text { on the board }\end{array}$ & $\begin{array}{l}\text { Board policy - board operations } \\
\text { Governance as leadership }\end{array}$ \\
\hline $\begin{array}{c}\text { Self Reflection and Assessment } \\
\text { Regular reviews of the functions and } \\
\text { effectiveness of the board itself }\end{array}$ & $\begin{array}{l}\text { Self evaluation and external reporting } \\
\text { Shared governance (generative dialogue) }\end{array}$ \\
\hline $\begin{array}{c}\text { Assessing the level of trust within the } \\
\text { board and the quality of the group } \\
\text { process }\end{array}$ & $\begin{array}{l}\text { Self evaluation and external reporting } \\
\text { Strategic planning }\end{array}$ \\
\hline
\end{tabular}

\section{Acknowledgement}

Numerous people and organizations have made substantial contributions over the years to the development and evaluation of the Principle-Based Governance Model (Assurance). Appreciation is expressed to the school trustees and senior administration in the Fort Vermilion School Division, Grande Prairie Public School District, and Comox Valley School District who implemented components of the model. Recognition is provided to Dick Chambers, education consultant, who was instrumental in the development of the core governance construct.

\section{References}

Bassett, S., \& Westmore, K. (2012). Systems and processes that ensure high quality care. [Article]. Nursing Management - UK, 19(6), 18-20.

Blatstein, I. M. (2012). Strategic planning: Predicting or shaping the future? [Article]. Organization Development Journal, 30(2), 31-38.

Bradshaw, P. (2009). A contingency approach to nonprofit governance Nonprofit Management \& Leadership, 20(1), 61-82.

Bradshaw, P., Hayday, B., \& Armstrong, R. (2007). Non-profit governance models: Problems and Prospects. The innovation Journal: The Public Sector Innovation Journal, 13(3). Retrieved from http://www.innovation.cc/scholarly-style/bradshaw5final.pdf

Carr, R. (2010). Three public sector paradigms.

Chait, R. P., Ryan, W. P., \& Taylor, B. E. (2005). Governance as leadership: An interview with Richard P. Chait. BoardSource and Wiley, V(2), 2-3.

Clawson, J. G. (2009). Level three leadership: Getting below the surface (4th edition) Retrieved from University of Phoenix, eBook Collection.

Horswill, R. A. (2003). The development of an organizational performance model applicable to the Corporate Services Department. Masters of Business Administration, Royal Roads University, Victoria, BC Canada.

Ibarra-Colado, E., Clegg, S. R., Rhodes, C., \& Kornberger, M. (2006). The ethics of managerial subjectivity. Journal of Business Ethics, 64(1), 45-55. Retrieved from doi:10.1007/s10551-005-3325-z. 
Inspiring education working group Group B governance Prototype: Sharing governance and principle-based decision making. (2009).

Jones, G. R. (Ed.). (2007). Organizational theory, design, and change (5th ed.). Upper Saddle River, NJ: Prentice Hall.

Kaplan, R. S., \& Norton, D. P. (2008). Mastering the management system. Harvard Business Review, 86(1), 62-77. Retrieved from EBSCOhost.

Kouzes, J. M. (2003). Business leadership Retrieved from University of Phoenix, eBook Collection

Liedtka, J. (1998). Constructing an ethic for business practice: Competing affectively and doing good. Business and Society, 37(3), 254-280. Retrieved from ABI?INFORM Global database. (Document ID: 33710634)

Lipman, F. D. (2007). Summary of major corporate governance principles and best practices. [Article]. International Journal of Disclosure \& Governance, 4(4), 309-319. doi: 10.1057/palgrave.jdg.2050064

Marin, J.-C. (2012). The impact of strategic planning and the balanced scorecard methodology on middle managers' performance in the public sector. [Article]. International Journal of Business \& Social Science, 3(1), 114-127.

McCue, D., \& McCue, G. (Eds.). (2002). The Spiral Stair: Leading Organizations Towards Sustainability. Victoria, BC.

Palepu, K. G., Healy, P. M., \& Bernard, V. L. (2004). Business analysis \& valuation: Using financial statements (3rd edition) Retrieved from University of Phoenix, eBook Collection.

Payne, D., Raiborn, C., \& Askvik., J. (1997). A global code of business ethics. Journal of Business Ethics, 16(16), 1727-1735. Retrieved from ABI/INFORM Global. (Document ID: 23172447).

Rotary International Guiding Principles (Vol. 2012). (2012). Retrieved October 2012, 2012, from http://www.rotary.org/en/aboutus/rotaryinternational/guidingprinciples/pages/ridefault.aspx

Smith, B. N., Montagno, R. V., \& Kuzmenko, T. N. (2004). Transformational and servant leadership: content and contextual comparisons. Journal of Leadership \& Organizational Studies, 4(80-91). Retrieved from ABI/INFORM Global database. (Document ID 692436991)

Warren, M. (2011). Ethics and professionalism in a changing world: No right way to do a wrong thing. Paper presented at the Texas Association of Counties, Austin, Texas.

Webster's collegiate dictionary. (1989). (Ninth ed.). Springfield MA: Merriam-Webster Inc.

\section{Copyright Disclaimer}

Copyright reserved by the author.

This article is an open-access article distributed under the terms and conditions of the Creative Commons Attribute License (http://creativecommons.org/licenses/by/3.0/). 